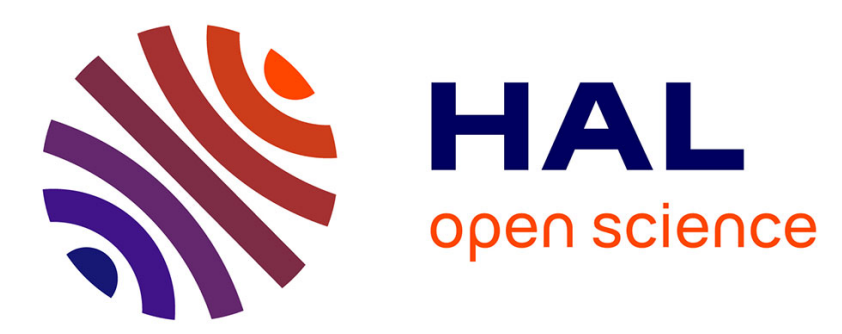

\title{
Parameters of Vacuum Process as the Factors Changing the Growth Kinetics of Chromized Layers Produced on Low-Carbon Iron Alloys by Means of CVD \\ E. Kasprzycka
}

\section{- To cite this version:}

E. Kasprzycka. Parameters of Vacuum Process as the Factors Changing the Growth Kinetics of Chromized Layers Produced on Low-Carbon Iron Alloys by Means of CVD. Journal de Physique IV Proceedings, 1995, 05 (C5), pp.C5-175-C5-182. 10.1051/jphyscol:1995519 . jpa-00253844

\author{
HAL Id: jpa-00253844 \\ https://hal.science/jpa-00253844
}

Submitted on 1 Jan 1995

HAL is a multi-disciplinary open access archive for the deposit and dissemination of scientific research documents, whether they are published or not. The documents may come from teaching and research institutions in France or abroad, or from public or private research centers.
L'archive ouverte pluridisciplinaire HAL, est destinée au dépôt et à la diffusion de documents scientifiques de niveau recherche, publiés ou non, émanant des établissements d'enseignement et de recherche français ou étrangers, des laboratoires publics ou privés. 


\title{
Parameters of Vacuum Process as the Factors Changing the Growth Kinetics of Chromized Layers Produced on Low-Carbon Iron Alloys by Means of CVD
}

\author{
E. Kasprzycka \\ Institute of Precision Mechanics, 3 Duchnicka Street, 00-967 Warsaw, Poland
}

\begin{abstract}
Chemical vapour deposition of chromium on the surface of low-carbon iron alloys has been investigated using a novel CVD method that combines the low cost of pack metallisation with the advantages of vacuum technique. Chromizing processes have been carried out in a hot-wall vacuum oven with a mass spectrometer to determine the chernical composition of residual gases. The processes have been performed in chromium chlorides atmosphere at a low pressure range from 1 lo $800 \mathrm{hPa}$, the treatment temperature 800 to $950^{\circ} \mathrm{C}$. The effect of the vacuum level during the process and the process parameters such as time and temperature on the growth kinetics of diffusion layers has been determined. Studies of layer thickness, its morphology, its phase composition. $\mathrm{Cr}$ and $\mathrm{Fe}$ depth profiles in the diffusion zone of chromized layers have been conducted. The investigations have proved that the chromizing process under low pressure, with static vacuum instead of dynamic vacuum conditions during the holding is the most effectjve as far as the growth kinelics of diffusion layers is concerned. It has been shown that the kinetics of the process is controlled by the diffusion of chromium in the steel.
\end{abstract}

\section{INTRODUCTION}

Diffusion chromizing is one of many types of thermochemical treatment employed today for improving properties of steel surface such as microhardness, wear or oxidation, and corrosion resistance $[1-7]$. Corrosion resistance is characteristic of monophase layers of chromium in an $\alpha$-Fe solid solution structure. Chromized layers of that structure can be obtained only or the pure iron or on special low-carbon steels stabilized by means of strong carbidizing elements (Ti, Nb, V) binding the carbon in steel as the stable carbides [8]. The diffusion chromizing by CVD consists in holding steel at the temperature over $800^{\circ} \mathrm{C}$ in chromiun compounds (e.g. chlorides) atmosphere [9]. Chromium is transferred to the steel surface by one or more of several possible deposition reactions (of interchange, of reduction, or of thermal dissociation types) and then it diffuses in it to create a layer. The process must be conducted in the absence of air to prevert oxidation of metallic chromium which is the chromium source.

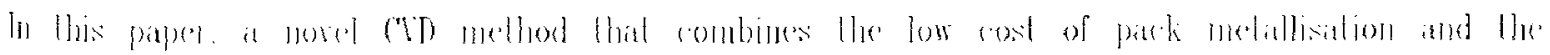

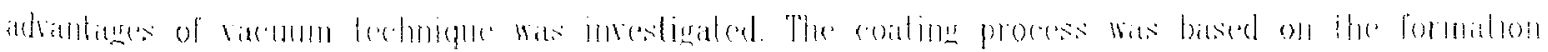


of chromium chlorides atmosphere in situ during the processing. A metallic chromium powde: mixture with a halide activator $\left(\mathrm{NH}_{4} \mathrm{C}\right)$ were used as reagents. The proposed method was obtainet by means of heating a batch in a dynamic vacuum and then holding it in a static vacuum $[10,1]$ Usually, in vacuum techniques, the dynamic vacuum is used, maintained by continuously workin: vacuum pumps which take away atmosphere components from the reaction chamber. However, if such conditions, also reactive vapours e.g. chromium chlorides, necessary to produce a layer, are taken away, and consequently, the effectiveness of the process is reduced.

This problem can be avoided when we maintain the holding in a static vacuum during the chromizing process. Neither the gases nor vapours are taken away in such conditions, because a closed system is obtained when the pump is turned off. There is no information about the chromizing process carried out in such a way. The objective of this paper was to determine the effect of the vacuum level during the process and the process parameters such as time and temperature on layer diffusion growth on low-carbon iron alloys.

\section{EXPERIMENTAL,DETAILS}

\subsection{Chromizing process}

The chromizing processes were carried out in a hot-wall vacuum oven with a mass spectrometer (topatron) to measure the partial pressures and to determine the chemical composition of residual gases whose range was from $M=2$ to $M=100$ of their molecular mass. The oven construction makes it possible to continuously control and to check the temperature range from 20 to $1100^{\circ} \mathrm{C}$ and io control the pressure from $1 \mathrm{~Pa}$ to $10^{5} \mathrm{~Pa}$. Crucibles of high temperature-resistant steel were used containing steel samples in contact with a powder mixture, composed of metallic pure chromium $(75 \%)$, ammonium chloride $(1 \%)$ and kaolin (14\%). After the crucibles were put in a vacuum retort, the pumping system started and the oven heating was activated. After the process was over, the batch was cooled in the oven

\subsection{Methods of layer examinations}

The layer examinations included: phase composition, layer microstructure, thickness measurements $\mathrm{Cr}$ and $\mathrm{Fe}$ depth profiles in the layer diffusion zone. The investigations were realized on polished samples made of Armco-iron and low-carbon steel containing: $0.05 \% \mathrm{C}, 0.35 \% \mathrm{Si}, 0.65 \% \mathrm{Mr}$ $0.10 \% \mathrm{Cr}, 0.09 \% \mathrm{Ni}, 0.03 \% \mathrm{Nb}, 0.02 \% \mathrm{Co}, 0.98 \% \mathrm{Tj}$. The phase composition of the surface of chromized

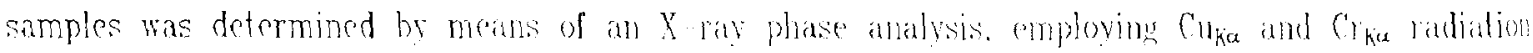

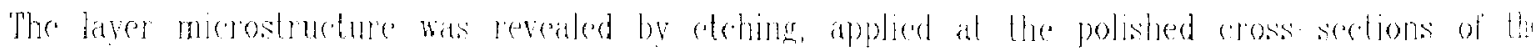


specimens. An optical microscope and an X-ray microanalyser were used to determine the layer thickness. The $\mathrm{Cr}$ and $\mathrm{Fe}$ depth profiles in the layer diffusion zone were determined by means of an $X$-ray microanaliser too.

\section{RESULTS AND DISCUSSION}

\subsection{Layer constitution}

An X-ray surface analysis of the chromized samples made of Armco-iron and low-carbon steel revealed the presence of solid solution of $\mathrm{Cr}$ in $\alpha$-Fe and some $\mathrm{M}_{2} \mathrm{~N}$ nitrides. The structures of chromized layers and $\mathrm{Cr}$ and $\mathrm{Fe}$ depth profiles in their diffusion zone are shown in Fig.1. The layers are unetched, as opposed to the steel core. The profiles of $\mathrm{Cr}$ and $\mathrm{Fe}$ concentration in the diffusion zone of chromized layers show that the layers should be treated as solution layers, because the sum of $\mathrm{Cr}$ and $\mathrm{Fe}$ content at successive points of concentration profiles is always about 100\%. The distinct line separating the layer from the ferritic core, visible in Fig.1b, corresponded to the jump of $\mathrm{Cr}$ and $\mathrm{Fe}$ concentration on the depth profiles caused by phase transformation from $\gamma$-Fe to $\alpha-F e$ at the process temperature $\left(950^{\circ} \mathrm{C}\right)$ according to $\mathrm{Fe}-\mathrm{Cr}$ phase diagram. The absence of the distinct line separating the layer from the core, visible in Fig. 1a, when the processes are carried out at lower temperatures (e.g. $800,850^{\circ} \mathrm{C}$ ), can be explained by the fact that diffusion below $850^{\circ} \mathrm{C}$ occurs mainly in ferrite without a phase transformation.

\subsection{Static and dynamic vacuum influence}

The scheme of temperature and pressure change during the chromizing process in dynamic and static vacuum conditions is shown in Fig. 2. The pressure increase to about $0.5 \mathrm{hPa}$ over the temperature of $350^{\circ} \mathrm{C}$ during the heating (Fig. 2b,c) was caused by thermal dissociation reactions of ammonium chloride $\left(\mathrm{NH}_{4} \mathrm{Cl} \rightarrow \mathrm{NH}_{3}+\mathrm{HCl}\right)$ and then ammonia $\left(2 \mathrm{NH}_{3} \rightarrow \mathrm{N}_{2}+3 \mathrm{H}_{2}\right)$. With the dynamic vacuum, when the process temperature is reached, the pressure in the oven successively decreases for nearly a value range from $0,1 \div 1.0 \mathrm{hPa}$ to about $0.01 \mathrm{hPa}$ (Fig. 2b).

In another case (Fig. 2c), when the static vacuum is used during the holding (when the vacuum pump is turned off), first the oven pressure jumps from $0.1 \div 1.0 \mathrm{hPa}$ to $400 \div 800 \mathrm{hPa}$ and then remains quasi-constant. An analysis of chemical composition of residual gases as soon as the process temperature is reached revealed, at the tolal pressure about $0.1 \mathrm{~h} \mathrm{~Pa}$, the presence of $\mathrm{N}_{2}$ and $\mathrm{CO}$ which jointly constitute $46 \%$ of the total gas volume, $\mathrm{H}_{2}$ about $18 \%, \mathrm{H}_{2} \mathrm{O}$ about $16 \%$ and the other residual gases such as 0 ? and (c)? below 3 .' (Fir 3 ). 


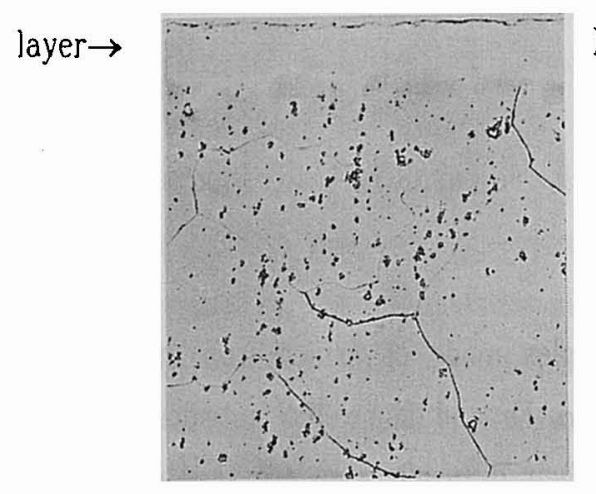

layer $\rightarrow$
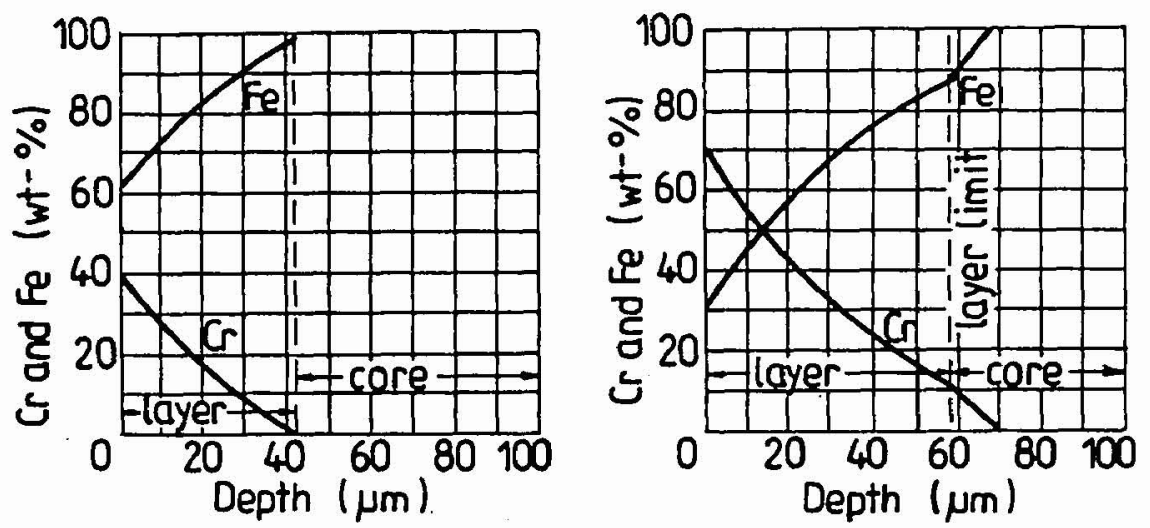

Figure 1: Microstructure and $\mathrm{Cr}$ and $\mathrm{Fe}$ depth profiles of chromized layers produced on low-carbon steel during $10 \mathrm{~h}$ at the temperatures a $-850^{\circ} \mathrm{C}, \mathrm{b}-900^{\circ} \mathrm{C}$.

a

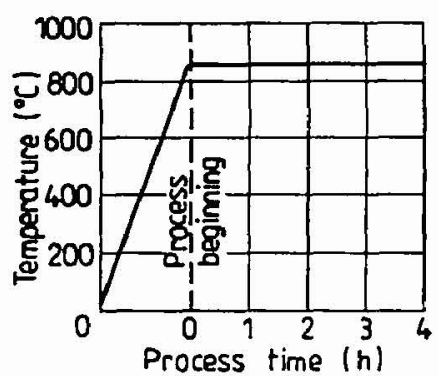

b

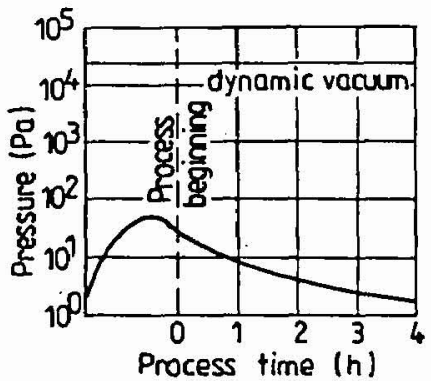

c

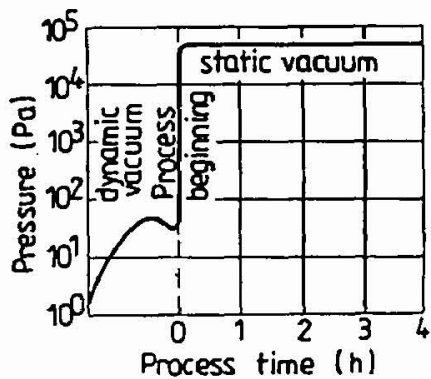

Figure 2: Scheme of temperature changes $(a)$ and pressure $(b, c)$ during chromizing process: b-dynamic vacuum, c-dynamic vacuum during the heating and static vacuum applied during the holding time. 


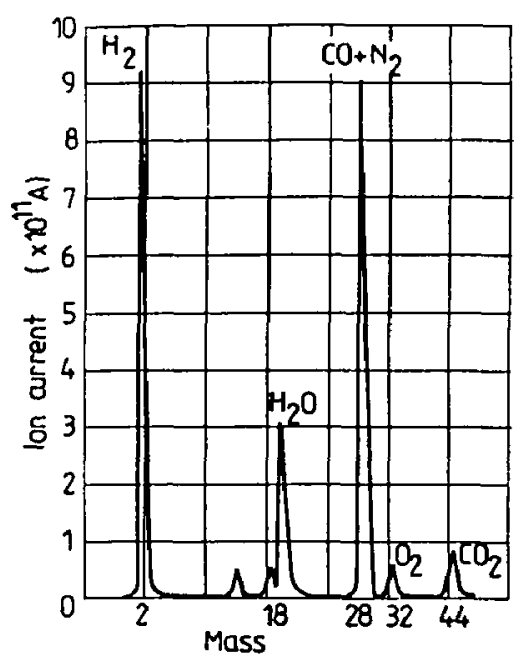

Figure 3: Mass spectrogram of residual gasses in vacuum oven during chromizing process.

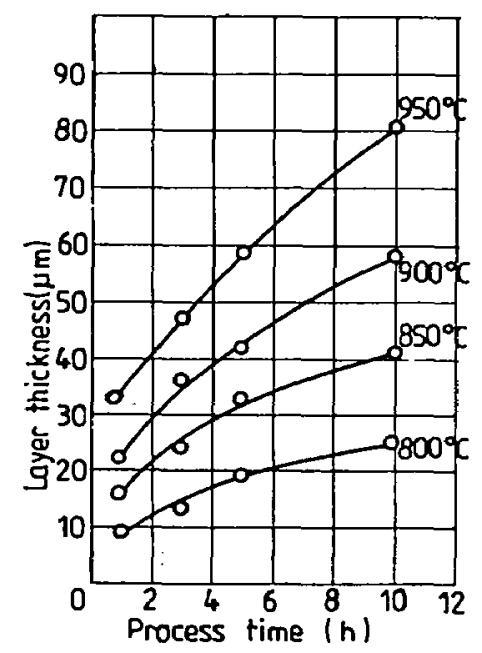

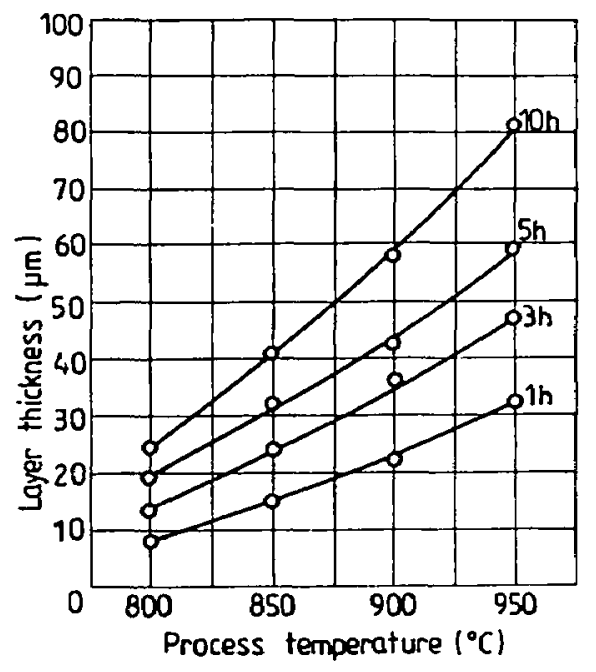

Figure 4: Layer thickness of chromized low-carbon steel as a function of temperature for a given time of treatment.

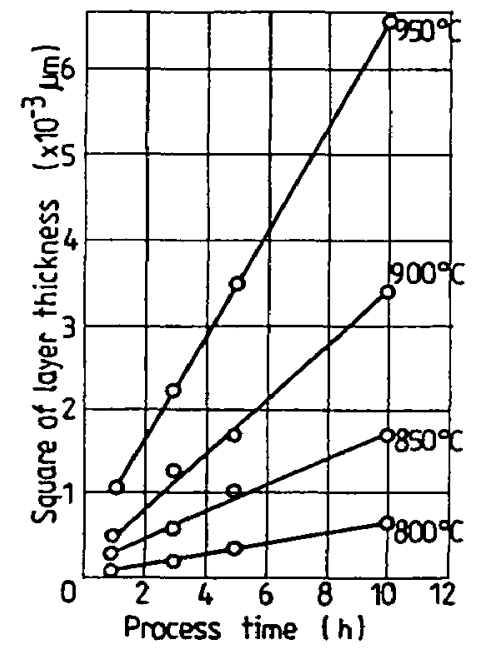

b

Figure 5: Layer thickness (a) of chromized low-carbon steel and square of layer thickess (b) as a function of process time for various temperatures. 
A comparison was made of layer thickness produced on Armco-iron and low-carbon steel by meat of static and dynamic vacuum conditions during the holding at: $850^{\circ} \mathrm{C}, 950^{\circ} \mathrm{C}$ within $5 \mathrm{~h}$ and $10 \mathrm{~h}$ the static vacuum conditions during the holding, the layer thickness is greater than in the dynuns: vacuum, (Table 1). For instance, the layer thickness on low-carbon steel at $950^{\circ} \mathrm{C}(10 \mathrm{~h})$ in dynam: vacuum conditions equals $39 \mu \mathrm{m}$, but in the static vacuum conditions. the layer thickness increast two times to $81 \mu \mathrm{m}$.

Table1. Layer thickness on Armco-iron and low-carbon steel produced in chromizing process in dynamic vacuum and in static vacuum conditions during the holding

\begin{tabular}{|c|c|c|c|c|c|c|}
\hline \multirow[b]{2}{*}{ Steel grade } & \multirow{2}{*}{$\begin{array}{l}\text { Process } \\
\text { temperature } \\
\left({ }^{\circ} \mathrm{C}\right)\end{array}$} & \multirow{2}{*}{$\begin{array}{c}\text { Process } \\
\text { tome } \\
(h) \\
\end{array}$} & \multicolumn{4}{|c|}{ Layer thickness $(\mu \mathrm{m})$} \\
\hline & & & Static & $\begin{array}{l}\text { Vacuum } \\
X_{s}\end{array}$ & $\begin{array}{c}\text { Dynamic Vacuum } \\
X_{d}\end{array}$ & $\overline{X_{\mathrm{s}} / \mathrm{A}_{\mathrm{d}}}$ \\
\hline \multirow{3}{*}{ Armeo-jron } & 850 & 5 & & 27 & 10 & 2.7 \\
\hline & & 10 & & 38 & 15 & 2.6 \\
\hline & 950 & $\begin{array}{r}5 \\
10\end{array}$ & & $\begin{array}{l}53 \\
75\end{array}$ & $\begin{array}{l}22 \\
32\end{array}$ & $\begin{array}{l}2.4 \\
2.3\end{array}$ \\
\hline \multirow{3}{*}{ Low-carbon steel } & 850 & 5 & & 32 & 13 & 2.5 \\
\hline & & 10 & & 41 & 15 & 2.6 \\
\hline & 950 & $\begin{array}{r}5 \\
10\end{array}$ & & $\begin{array}{l}59 \\
81\end{array}$ & $\begin{array}{l}26 \\
39\end{array}$ & $\begin{array}{l}2.3 \\
2.0\end{array}$ \\
\hline
\end{tabular}

\subsection{Influence of time and temperature on layer growth kinetics}

The layer growth kinetics on low-carbon steel surface has been studied by performing a series 0 chromizing processes for various times: 1, 3, 5, 10 h at the temperatures of: 800, 850, 900, 950 The influence of time and temperature on layer thickness is illustrated in Fig. 4. which gives the varjation of thickness as the function of temperature for a given time of treatment, and in Fig. $j$ shows the layer thickness as the function of time at a given temperature. When the square of the layer thickness is plotted against time for various temperatures, straight lines are obtained, $a$ shown in Fig. 5b. The linear dependence of the square of the layer thickness on the process time suggests that the chromizing process is controlled by diffusion in the steel.

\section{CONCLUSIONS}

The investigations carried out in this research work have proved that the vacuum level kept during the chromizing process as well as the process time and temperature influenced significantly the growth of diffusion layers. These diffusion layers produced on Armco-iron and on special low-cabon steel contaning anong others $0.98 \%$ Ti have a structure consisting of a solid solutio 
chromium in $\alpha-\mathrm{Fe}$ and some $\mathrm{M}_{2} \mathrm{~N}$ nitrides. It has been shown, that the chromizing process under low pressure, in static vacuum instead of dynamic vacuum conditions during the holding, is more effective as far as the growth kinetics of diffusion layers is concerned. Moreover, it has been proved that the kinetics of the chromizing process is controlled by the diffusion of chromium in the steel.

\section{REFERENCES}

[1] Meier G.H., Cheng C., Perkins R.A., and Bakker W., Surf. and Coat. Techn. 9/40 (1989) 53-64.

[2] Jyrkäs K., and Lajunen L.H.J., Surf. Eng. 6 (1990) 113-119.

[3] Jyrkäs K., Surf. Eng. 7 (1991) 239-249.

[4] Eastwood B., Harmer S., Smith J. and Kempster A., Mat. Sc. Forum 102-104 (1992) 534-552.

[5] Lunina M.N., Met. Sci. Heat Treat. 35 (1993) 88-91.

[6] Kasprzycka E. and Tacjkowski J., Mechanik 4 (1991) 159-161.

[7] Kasprzycka E., Pietrzak K. and Tacikowski J., Thin Films. Proceedings of the joint 4th International Symposium on Trends and New Applications in Thin Films-TATF'94 and the 11th Conference on High Vacuum, Interfaces and Thin Films-HVITF'94, Germany, Dresden 7-11 March, DGM Verlag, 1994, pp 670-673.

[8] Beker G., Daves K., and Steinberg F., Stähl und Eisen 61 (1941) 289-294.

[9] Dubinin G.N., Diffusion Chromizing of Alloys, Mashinostroenie. Moscow. 1964, pp. 57-105.

[10] Kasprzycka E., Elaboration of Diffusion Chomizing Method on Armco Iron and Low-Carbon Steel under Low Pressure, Doctor's Thesis, Institute of Precision Mechanics, Warsaw, 1988, pp 52-70.

[11] ] Kasprzycka E., Tacikowski J., and others, Method of Vacuum Chromizing Process of Steel, Poljsh Standard No P-159 325, Warsaw 1993. 